\title{
A NATUREZA DO ESTADO CAPITALISTA NA ÓPTICA DOS FUNDADORES DA CIÊNCIA ECONÓMICA
}

1 - Não é preciso estudar Marx e Engels para nos apercebermos da natureza de classe do estado.

Basta acompanhar o processo que levou à transformação das comunidades primitivas em sociedades esclavagistas para ver claramente como surgiu o estado enquanto estado de classe.

Nos tempos primitivos, os homens viviam e trabalhavam juntos, em comunidades que caçavam em grupo e partilhavam em conjunto os resultados da caça. Esta forma comunitária de vida explica-se, aliás, facilmente, se tivermos presente que os homens primitivos precisavam de se unir e de actuar em grupo, quer para se defenderem dos animais selvagens quer para poderem prover à sua alimentação, tarefas que tinham de levar a cabo com instrumentos mais que rudimentares. Como Marx salienta numa carta para Vera Zassoulitch, é a necessidade do trabalho colectivo inerente às condições de vida próprias das comunidades primitivas que explica a propriedade comum da terra, e não o contrário.

* Aula Magna proferida na Faculdade de Direito da UFPR (05.03.2007)
Não fazia sentido, então, falar-se de propriedade (privada) dos meios de produção, que eram utilizados por toda a colectividade (tal como a terra) para satisfazer as necessidades de todos. Não havia, nestas comunidades, diferenciação social, nem divisão da sociedade em classes, nem exploração de uma classe de homens por outra. Nestas sociedades primitivas, em que a organização colectiva e a disciplina do trabalho resultavam da força do costume, do prestígio e do poder de que gozavam certos elementos da comunidade (os chefes de clãs, que não raras vezes eram mulheres), não havia, por isso, necessidade de qualquer aparelho de coerção destinado a garantir a 'exploração do homem pelo homem', o domínio de uma classe social sobre outra(s) classe(s) social (sociais). Não havia lugar para o Estado enquanto aparelho de poder (político, judiciário e militar) ao serviço da manutenção de determinado status quo.

Entretanto, a lenta acumulação de invenções foi aumentando a produtividade do trabalho. Assim se foram criando condições para que as comunidades primitivas produzissem, além do necessário à sobrevivência, um excedente (sobreproduto 
social). Assim se puderam constituir reservas de alimentos, reduzindo o risco da ocorrência de períodos de fome. Assim foi possível uma divisão do trabalho mais avançada e o consequente aumento da população (fenómeno que é, ele próprio, revelador da existência de um excedente social). Este aumento da população abre, por sua vez, novas possibilidades de especialização e de divisão do trabalho, ampliando a quantidade e a eficiência das forças produtivas à disposição da humanidade.

A existência de um excedente regular e permanente de alimentos tornou possível o início da agricultura, da domesticação e da criação de animais, actividades que pressupõem necessariamente a existência de uma certa reserva de alimentos. E esta foi a base material necessária para que pudesse acontecer a grande revolução económica e social do período neolítico - a revolução neolítica, como justamente lhe chamam os autores. Esta 'revolução' (este salto na produtividade do trabalho humano) trouxe pela primeira vez ao homem a possibilidade de controlar a produção dos seus meios de subsistência, ao mesmo tempo que veio abrir novas perspectivas de desenvolvimento do artesanato profissional, com o consequente aperfeiçoamento dos instrumentos de produção, acarretando profundas modificações no modo de vida e nas relações entre os homens.

Surgiu então uma grande diferenciação entre as tribos que continuaram uma vida nómada, vivendo essencialmente da caça, e aquelas que adoptaram uma actividade económica que permitiu (e exigiu) a sedentarização. E começou então a desenvolver-se a primeira importante divisão social do trabalho entre as tribos que se dedicaram à pastorícia e as que se dedicaram à cultura da terra.

Com a cultura da terra, o nomadismo foi sendo progressivamente abandonado, e, com a sedentarização, começaram as famílias a reservar normalmente as mesmas terras para a sua agricultura, assim se generalizando a utilização particular das terras na posse de cada família, embora, durante muito tempo, esta posse continuasse a ter como pressuposto a existência da comunidade e a propriedade colectiva da terra. A produtividade do trabalho aumentou nestas comunidades, que passaram a poder produzir regularmente uma quantidade de bens muito superior à necessária para satisfazer as suas necessidades, ampliando assim o excedente social.

A agricultura desenvolveu-se, passando a adequar-se as sementeiras e as colheitas às estações do ano, uma vez compreendida a importância da energia do sol. Por outro lado, nos vales do Nilo, do Tigre e do Eufrates reconheceu-se o valor das águas como reconstituinte da fertilidade das terras e iniciou-se a prática da irrigação. A produção de alimentos aumentou de tal forma que, entretanto, com a descoberta dos metais (cobre e estanho - o ferro só bastante mais tarde), da arte de trabalhá-los e de fazer ligas (bronze), foi possível operar-se uma nova divisão do trabalho entre a agricultura e o artesanato (a indústria). A sociedade estava agora em condições de alimentar milhares de homens que não tinham de produzir alimentos, podendo dedicar-se exclusivamente às actividades 'industriais'. Foi o período em que se descobriram a roda de cerâmica, os carros de rodas, o arado com ponta de metal, os barcos à vela, a técnica do fabrico de tijolos 
(com importantes consequências ao nível da construção, tanto para fins civis como para fins religiosos). Com a técnica da irrigação, surgiu, verdadeiramente, a civilização.

A utilização de novos e mais aperfeiçoados instrumentos de trabalho e de novas técnicas agrícolas aumenta enormemente a produtividade do trabalho. Nos tempos primitivos, o homem não era capaz de produzir mais que a sua subsistência; agora produz-se um excedente, que se transforma em objecto de trocas entre os homens, assim se iniciando a troca de produtos como acto corrente da vida em sociedade.

Mas, se cada homem pode produzir, com o seu trabalho, mais que o necessário para a sua subsistência, ganha sentido $a$ exploração do homem pelo homem. Nos tempos primitivos era corrente a prática do infanticídio, bem como o abandono ou a morte dos deficientes e dos velhos (aqueles que não eram capazes de assegurar a sua própria subsistência), com o fim de evitar a população excessiva, a fome e o possível extermínio de toda a comunidade. Por isso mesmo as tribos vencedoras matavam (e às vezes comiam) os seus prisioneiros de guerra. Agora, torna-se vantajoso fazê-los escravos e obrigá-los a trabalhar para que os senhores possam apropriar-se do excedente criado pelo trabalho escravo.

A primitiva comunidade de vida e de trabalho foi assim destruída pelo progresso das técnicas, pela divisão do trabalho e pelas consequências desta: a divisão da sociedade em classes e o aparecimento do estado como instrumento de domínio de um grupo social sobre outro. Na lição de Engels:

"O aumento da produção em todos os ramos - criação de gado, agricultura, ofícios domésticos - deu à força de trabalho humana a capacidade de conseguir um produto maior do que o necessário para a sua subsistência. (...) A introdução de novas forças de trabalho tornou-se desejável. A guerra forneceu-as: os prisioneiros de guerra foram transformados em escravos. A primeira grande divisão social do trabalho, com o seu aumento da produtividade do trabalho, e portanto da riqueza, e o alargamento do campo da produção, trouxe consigo, necessariamente, naquelas condições históricas, a escravatura. Da primeira grande divisão social do trabalho resultou a primeira grande divisão da sociedade em duas classes: senhores e escravos, exploradores e explorados". ${ }^{1}$

O modo de produção e a organização social próprios do comunismo primitivo deram lugar a um novo modo de produção e a uma diferente organização social, o esclavagismo, que, enquanto modo de produção, assenta na exploração do trabalho forçado da mão-deobra escrava pelos proprietários das terras: os senhores alimentam os seus escravos e apropriam-se do (restante) produto do trabalho destes. O estado esclavagista foi a estrutura que garantiu as condições para o funcionamento da economia nestas primeiras sociedades divididas em classes. Com o esclavagismo surgiu a primeira forma de estado de classe.

2 - Também no quadro do feudalismo tudo era claro no que concerne à estrutura $\mathrm{e}$ à natureza do poder político, cuja titularidade coincidia com a titularidade do poder económico.

${ }^{1}$ Cfr. MARX/ENGELS, Obras Escolhidas, ed. cit., II, $357 / 358$. 
Os grandes senhores proprietários de terras detinham todos os atributos do estado dentro das fronteiras dos seus domínios: podiam constituir exércitos e mobilizar os seus súbditos para eles; decidiam sobre a guerra e a paz; administravam a justiça; cunhavam moeda; cobravam impostos. O poder político, representado por este estado fragmentado, estava abertamente ao serviço dos interesses económicos da classe dominante: os titulares do poder político utilizavam-no para dirigir a economia e para garantir os seus interesses económicos, sociais e políticos.

Nas condições do feudalismo, a força de trabalho continuava a não ser uma mercadoria autónoma, porque os servos, não sendo homens livres, não eram livres de vender a sua própria força de trabalho: tinham de a exercer nas terras do senhor, em parte para garantir a sua própria sobrevivência e reprodução, em parte, obrigatória e gratuitamente, em benefício do senhor. Como contrapartida, os servos tinham o direito de trabalhar as terras indispensáveis para obter os meios de subsistência para si e para as suas famílias, e o senhor não podia expulsá-los da terra que habitavam (tal como os servos não podiam abandoná-la).

Quer isto dizer que os servos não estavam separados dos meios de produção, uma vez que tinham garantido o acesso aos meios materiais da sua existência, o que lhes permitia viver do seu próprio trabalho utilizando os instrumentos de produção com os quais estabeleciam uma relação directa. O que significa que eles não eram economicamente obrigados a trabalhar nas terras do senhor. Eles eram obrigados a trabalhar gratuitamente para o seu senhor em virtude do estatuto jurídico - político da servidão a que estavam sujeitos. ${ }^{2}$

E este estatuto era respeitado porque os senhores tinham o direito e o poder (político, militar e judicial) de os compelir a isso, e porque os próprios servos se sentiam obrigados a respeitar o seu estatuto, na medida em que aceitavam a ideologia dominante, veiculada principalmente pela Igreja Católica, que advogava uma sociedade hierarquizada, em que tudo e todos estavam no seu lugar e não podiam deixar de estar, sob pena de se pôr em risco o equilíbrio indispensável à própria sobrevivência do edifício social.

Neste sentido, pode dizer-se que as relações de produção eram, no quadro do feudalismo, relações entre os produtores directos e o seu suserano, verificando-se a exploração dos produtores através de uma compulsão político - legal directa (Maurice Dobb): a apropriação do trabalho excedente pelos senhores feudais efectuava-se directamente, por coerção extra-económica, sem a mediação das leis económicas de troca de mercadorias. "A possibilidade de apropriação do sobreproduto por parte do senhor - escreve G. Conte ${ }^{3}$ - reside unicamente no poder de impor o seu direito, enquanto proprietário nominal da terra, pela coerção jurídica ou pela pura violência".

Nos tempos feudais, como sublinha Galbraith, "a propriedade era uma fonte duradoura de poder temporal." ${ }^{4} \mathrm{O}$ poder

\footnotetext{
${ }^{2}$ Cfr. G. CONTE, Da Crise..., cit., 12ss e A. GUERREAU, O Feudalismo..., cit., $215 \mathrm{ss}$.

${ }^{3}$ Últ. ob. cit., 15.

${ }^{4}$ Cfr. J. K. GAlBRAITH, Anatomia do Poder, cit., 110.
} 
político, que tinha a origem e o fundamento na propriedade da terra, era um poder descentralizado e fragmentado, disperso por uma pluralidade de titulares, dando a ideia da ausência do estado. Mas o poder político (o estado, hoc sensu) existia, exercendo-se a sua autoridade de pessoa para pessoa. Charles Parain observa que "o facto essencial, sob este aspecto, é que a justiça é exercida pelo ‘suserano' sobre os seus vassalos e pelo 'senhor' sobre os camponeses. A exploração das prestações económicas e o aparelho jurídico - político encontram-se, por isso mesmo, muito estreitamente unidos". ${ }^{5}$

A natureza de classe do estado aparece, nestas condições, sem qualquer dúvida nem disfarce, o mesmo podendo dizer-se quanto à importância decisiva do estado feudal (da instância jurídico-político-ideológica) para a manutenção das estruturas económicas, sociais e políticas do feudalismo. O poder político e a violência que ele representa eram exercidos directamente pela classe dominante (que dispunha do poder militar e administrava a justiça através de tribunais nomeados pelos senhores e responsáveis perante eles) para garantir a apropriação do sobreproduto criado pelos trabalhadores servos e, em último termo, para defesa dos seus interesses de classe, que exige a manutenção do estatuto de servidão e das relações de produção servis.

Acompanhemos a lição de Marx: ${ }^{6}$

"É precisamente porque a sociedade se baseia na dependência pessoal que todas as relações sociais aparecem como relações entre pessoas. Os trabalhos diversos e os seus produtos não carecem, por isso, de adoptar

\footnotetext{
${ }^{5}$ Cfr. PARAIN e outros, cit., 26.

${ }^{6}$ Cfr. K. MARX, Le Capital (trad. J. Roy), cit., 73.
}

uma figura fantástica distinta da sua realidade. Apresentam-se como serviços, prestações e entregas in natura. A forma natural do trabalho, a sua particularidade - e não a sua generalidade, o seu carácter abstracto, como na produção de mercadorias - é também a sua forma social. A corveia é medida pelo tempo do mesmo modo que o trabalho que produz mercadorias; mas cada prestador da corveia sabe muito bem, sem recorrer a um Adam Smith, que é uma quantidade determinada da sua força de trabalho pessoal que ele despende ao serviço do seu senhor. (...) De qualquer maneira que se julguem as máscaras que os homens trazem nesta sociedade, as relações sociais das pessoas nos seus trabalhos afirmam-se nitidamente como as suas próprias relações pessoais, em vez de se disfarçarem sob a forma de relações sociais das coisas, dos produtos do trabalho".

3 - O papel do novo estado começou a definir-se ainda antes da afirmação plena do capitalismo como sistema económico-social dominante, durante o longo período (processo) de acumulação primitiva do capital.

Marx sintetiza deste modo a leitura smithiana da previous accumulation: ${ }^{7}$

"Num tempo remoto, havia, de um lado, uma elite diligente, inteligente, e, sobretudo, frugal, e, do outro, uma escumalha preguiçosa, que dissipavam tudo o que tinha e mais. (...) Assim, aconteceu que os primeiros [a elite diligente, frugal e inteligente] acumularam riqueza e os últimos [a escumalha preguiçosa e perdulária], por fim, nada tinham para vender a não ser a sua própria pele. E deste pecado original datam a pobreza da grande massa, a qual continua, a despeito de todo o trabalho, a não ter nada para vender a não ser a si própria, e a riqueza de uns poucos, a qual cresce continuamente, embora eles há muito tenham deixado de trabalhar".

${ }^{7}$ Cfr. K. MARX, O Capital, Edições Avante, Livro Primeiro, Tomo III, Cap. XXIV, 807/808. 
Partilhamos com Marx a ideia de que “esta acumulação originária desempenha na economia política aproximadamente o mesmo papel que o pecado original desempenha na teologia": "A lenda do pecado original teológico conta-nos, certamente, como o homem foi condenado a comer o pão ganho com o suor do seu rosto; a história do pecado original económico, porém, revela-nos como é que há pessoas que não precisam de o fazer". Pois bem. Para sair deste plano ‘teológico', é necessário, a nosso ver, recorrer à história para tentar explicar como se concretizaram as duas condições que tornaram possíveis as relações de produção capitalistas: por um lado, a acumulação de capitais nas mãos de uma nova classe social; por outro lado, a separação dos produtores dos meios de produção e a emergência de uma nova classe social de trabalhadores livres.

Encurtando caminho, poderemos dizer que com a "revolução comercial" do século XVI, nomeadamente com a descoberta das novas rotas do comércio atlântico e de novos produtos comerciáveis (especiarias, escravos, etc.), e com a mundialização do comércio (a primeira onda de globalização) começou a moderna história do capital.

E ela só se compreende se tivermos em conta a participação decisiva do novo poder político (dos novos estados) que começava a afirmar-se na Europa, sob o impulso e a influência da burguesia comercial rica e culta. Foram estes estados nacionais que promoveram a colonização dos novos territórios e organizaram as operações de massacre de populações inteiras (nomeadamente das grandes civilizações da América Latina), o saque e a pilhagem das enormes riquezas desses povos e dessas regiões.
A este primeiro período de saque desenfreado seguiu-se a exploração sistemática dos territórios colonizados. Além de utilizarem mão-de-obra escrava, as potências colonizadoras impuseram aos povos indígenas das colónias pesados tributos, pagáveis em dinheiro, que apenas poderiam obter se trabalhassem para os colonizadores. Com este mesmo objectivo, foram utilizados outros meios de coerção, como a proibição de os povos colonizados cultivarem produtos comercializáveis, o confisco das suas terras de cultivo, o encargo cometido aos chefes tradicionais das colónias de enviarem jovens para trabalhar nas minas e nas plantações.

4 - Na Europa, a emergência da nova classe burguesa coincidiu com (e provocou) a progressiva proletarização da grande massa dos camponeses pobres. O instrumento mais poderoso deste violento processo foi a prática das enclosures (o acto de cercar os campos, incluindo as terras comunitárias, para nelas fazer apascentar enormes rebanhos de gado lanígero).

"Em todos os países da Europa ocidental produziu-se o mesmo movimento - escreve Marx $^{8}$ - embora varie a sua cor local ou se encerre num círculo mais estreito, ou apresente um carácter menos pronunciado ou siga uma ordem de sucessão diferente". Mas foi na Inglaterra que o movimento das enclosures encontrou a sua mais clara expressão e só aí (no séc. XVIII) o processo se radicalizou. As terras caem nas mãos da burguesia rica, interessada em extrair delas produtos que

\footnotetext{
${ }^{8}$ Ver K. MARX, Le Capital (trad. J. Roy), 529.
} 
pudesse comerciar. O desenvolvimento da indústria de panos na Flandres garantia mercado para a lã, a preços compensadores: não tardou, por isso, que a Inglaterra se transformasse num país "onde os cordeiros comem os homens" (Thomas Morus).

A ocupação e a vedação das terras comunais, inicialmente mitigada, veio a ser autorizada por lei do Parlamento (Bill for enclosures of commons, 1730): "no século XVIII - vejam o progresso!- a própria lei torna-se instrumento de espoliação, o que não impediu, de resto - ensina Marx ${ }^{9}$-, que os grandes proprietários tivessem recorrido também a pequenas práticas particulares, extra-legais".

E a prática das enclosures mostrou então em larga escala os seus efeitos: 1) reduziu as terras de cultivo; 2) privou os camponeses pobres dos meios de subsistência; 3) favoreceu o desenvolvimento da grande propriedade; 4) provocou a subida dos preços dos produtos alimentares; 5) conduziu ao despovoamento dos campos; 6) transformou os pequenos proprietários e rendeiros em jornaleiros, em "vendedores de si próprios", em "mercenários".

Estes efeitos foram de tal forma claros que, segundo a generalidade dos autores, por meados do séc. XVIII a Yeomanry (classe de pequenos camponeses livres) tinha sido liquidada na Inglaterra, deixando o campo livre para os grandes agricultores capitalistas que passam a recorrer à mão-deobra assalariada. ${ }^{10}$

\footnotetext{
${ }^{9}$ Cfr. Le Capital (trad. de J. Roy), cit., 535.
}

${ }^{10}$ Fenómeno análogo verificou-se nas Highlands da Escócia, mais para o final do séc. XVIII: os povos aí fixados, que viviam da agricultura, são expulsos para
A expulsão dos camponeses das terras que até então podiam utilizar para nelas prover à sua subsistência origina, por outro lado, o aparecimento de grandes massas de 'mendigos' e 'vagabundos' (desempregados), abandonados à maior miséria, sem possibilidades de grangear a sua subsistência a não ser que encontrassem trabalho como assalariados, o que não era fácil, dada a abundância de mão-de-obra desocupada. Forçados a mendigar e a roubar para não morrer, estes desgraçados sofreram um longo período de perseguições, já referidas por Thomas Morus na Utopia (1516).

Propunham alguns que esses 'mendigos' fossem enviados para as galés por toda a vida, enquanto outros propunham que se desenvolvessem as manufacturas para absorver a força de trabalho dos 'vagabundos' (produzir era resolver os problemas). Entretanto, considerada a 'mendicidade' um delito punido pelo estado, estes 'vagabundos' foram sujeitos a violentos castigos corporais, podendo ser reduzidos a escravos de quem os denunciasse, ou mesmo condenados à morte. Só no reinado de Henrique VIII terão sido executados $72000 .^{11}$

as terras - pouco férteis - junto ao mar, proibindo-selhes a emigração para o estrangeiro, a fim de os obrigar a afluir a Glasgow e a outros centros manufactureiros. Movimentos idênticos de ocupação das terras comunais ocorreram, embora com atraso no tempo em relação à Inglaterra, na generalidade dos países da Europa.

Alain Touraine refere práticas idênticas na América Latina, no início da industrialização. Para salvaguardar o seu nível de vida, nas condições resultantes do desenvolvimento da economia industrial, os grandes proprietários do Perú apropriaram-se pela violência das terras dos comuneros e cercaram-nas, provocando a desagregação das comunidades camponesas. Cfr. "La marginalidad urbana", em Revista Mexicana de Sociología, vol. XXXIX, nº 4, Dez/1977, 1.123.

${ }^{11}$ Cfr. K. MARX, Le Capital, trad. J. Roy, cit., 544. 
Como é bom de ver, foram estes 'vagabundos' que vieram a transformar-se em "mercenários" logo que as condições lhes permitiram vender a sua força de trabalho e encontrar quem pudesse e estivesse interessado em comprá-la. Este o processo que deu origem ao proletariado moderno das indústrias novas, nas sociedades capitalistas emergentes.

5 - Idêntico processo de proletarização ocorreu na indústria, por força do processo evolutivo que vai dos produtores autónomos da indústria artesana das cidades medievais até aos operários assalariados das maquinofacturas capitalistas. E também aqui o papel do estado foi decisivo.

As manufacturas resultaram em alguns casos do processo de transformação da antiga indústria artesana. Mas surgiram principalmente com a criação de novas indústrias, já sob a forma capitalista.

Os membros da classe burguesa tinham, entretanto, ocupado posições de maior destaque nos países mais avançados e o seu poderio económico foi-lhes propiciando um crescente poder político. Não admira, por isso, que o (novo) estado se tenha empenhado em incentivar e proteger a criação e o desenvolvimento das novas manufacturas capitalistas. Umas vezes, o estado criava manufacturas que administrava directamente (manufacturas reais); outras vezes, o Estado fomentava a constituição de manufacturas privadas às quais concedia privilégios monopolistas (manufacturas privilegiadas). Foi esta, como se sabe, a política desenvolvida por Colbert na França, pelos Stuarts na Inglaterra e, em Potugal, pelo Marquês de Pombal.
A importância do apoio do Estado às indústrias nacionais no período de arranque da indústria capitalista é assim sintetisada por Marx ${ }^{12}$ :

"Os diferentes métodos de acumulação primitiva que a era capitalista criou distribuem-se em primeiro lugar, por ordem mais ou menos cronológica, por Portugal, Espanha, Holanda, França e Inglaterra, até que esta os combina todos, no último terço do séc. XVII, num conjunto sistemático que abrange simultaneamente o regime colonial, o crédito público, a finança moderna e o sistema proteccionista. Alguns destes métodos assentam no emprego da força bruta, mas todos sem excepção exploram o poder do estado, a força concentrada e organizada da sociedade, a fim de precipitar violentamente a passagem da ordem económica feudal à ordem económica capitalista e abreviar as fases de transição. E, com efeito, a Força é a parteira de toda a velha sociedade em trabalho de parto. A Força é um agente económico".

Este apoio do Estado revestiu vários formas. Limitar-nos-emos a uma nota sobre a acção do estado-legislador.

O estado promulgou, em todos os países, legislação que proibia e considerava crimes as coligações operárias, as associações profissionais e o recurso à greve.

Recorde-se o remoto Statute of Labourers (promulgado na Inglaterra em 1349), no qual, a pretexto da diminuição acentuada dos trabalhadores em consequência da peste, se fixava um horário de doze horas de trabalho por dia e se proibia que os salários ultrapassassem um máximo determinado, mas não se previa qualquer salário mínimo. Na França, ficaram célebres as Ordonnances de Villers-Cotterêts (1539), que proibiam

${ }^{12}$ Cfr. O Capital, Cap. XXIV, em MARX/ENGELS, Obras Escolhidas, ed. cit., II, 145. 
"a todos os mestres, aos companheiros e serviçais de todos os mestres realizar qualquer congregação ou assembleia, grande ou pequena, seja para que assunto for, fazer qualquer monopólio e ter ou tomar qualquer combinação uns com os outros por causa da sua profissão, sob pena de confisco de corpo e bens". Estes princípios foram passando para sucessivas disposições legais, até à $L e i$ Le Chapelier (1791).

$\mathrm{Na}$ Inglaterra, desde o séc. XIV que as coalizões de trabalhadores eram consideradas entre os crimes mais graves. E assim se mantiveram as coisas, após a publicação das Combinations Acts (1789 e 1800), até 1824/1825, com a promulgação das leis que vieram autorizar a constituição de sindicatos e o recurso à greve.

Num tempo em que multidões de crianças, a partir dos seis anos de idade, trabalhavam nas manufacturas durante 17 e 18 horas em cada dia, em turnos diurnos e nocturnos, o estado - Sombart refere variadíssimos exemplos ${ }^{13}$ - obrigou as populações a um verdadeiro trabalho forçado nas manufacturas, nomeadamente na Espanha, na França, na Alemanha, na Holanda, na Suíça, na Áustria, na Inglaterra e na Rússia.

6 - Desfeito o sonho medieval de fazer da Cristandade um potência política, qual novo Sacro-Império Romano-Germânico, a política dos novos estados soberanos europeus passou a ter como objectivo assegurar a sobrevivência, a expansão, a riqueza e o poderio de cada um desses novos estados. E era corrente a ideia de que este

${ }^{13}$ Apud E. MANDEL, Traité..., cit., 1, 144. objectivo se poderia conseguir não só pelo reforço do poderio económico de cada país mas também (e porventura mais facilmente) pela via do enfraquecimento económico e político dos países vizinhos.

Considerando-se dada a quantidade de recursos disponíveis à escala mundial, concluía-se que um país só poderia enriquecer à custa de outro e admitia-se que a própria sobrevivência de um estado dependia de este ser capaz de assegurar o seu desenvolvimento económico e a sua riqueza mais rapidamente que o seu vizinho (e rival). Daí a importância do poderio militar, eventualmente necessário para subjugar outros povos pela via da guerra. Daí a rapacidade com que os próprios estados se comprometeram na conquista e na pilhagem dos territórios coloniais e na prática da mais violenta pirataria nos mares.

No contexto desta aceitação do antagonismo entre os interesses económicos das nações insere-se também a guerra do dinheiro em que os novos estados se empenharam, com o objectivo de obter mais ouro e prata que os outros países. Se "apenas uma determinada quantidade de dinheiro circula em toda a Europa - escreveu Colbert -, (...) não é possível aumentar o dinheiro em um reino sem o retirar simultaneamente, em quantidade idêntica, dos estados vizinhos".

O capitalismo anunciava-se, nos sécs. XVI e XVII, sob a forma de capitalismos nacionais e sob o signo do antagonismo entre os estados nacionais que suportavam as novas estruturas económicas. E os autores mercantilistas parece terem-se apercebido desta realidade ("o que convém a uma nação - sublinha Josiah Child - não convém a todas as outras"), que encontra eco nas conhecidas máximas de Montaigne: "nul ne 
gagne qu'un autre ne perde" ou "le profit de l'un est le dommage de l'autre".

A nação afirmava-se, assim, como espaço de poder (poder político e poder económico).

7- Ao contrário do liberalismo do séc. XIX, os mercantilistas não conceberam a ordem económica como algo separado da política nem defenderam que o estado nada tinha que ver com a actividade económica. Antes acentuaram o papel decisivo do estado no desenvolvimento da economia de cada nação. O económico estava, neste sentido, na dependência do político: as questões económicas constituíam a principal preocupação do estado. Por isso elas foram consideradas e estudadas, pelos mercantilistas, no âmbito da problemática relativa à organização do Estado. Este é um dos aspectos de modernidade dos mercantilistas.

De Colbert se disse que ele tinha a "mania da regulamentação". Cremos, porém, que não será inteiramente correcto considerar os mercantilistas em geral (incluindo Colbert) como maníacos da regulamentação. $\mathrm{Na}$ verdade, embora vendo o soberano como "o condutor supremo da máquina económica" (na expressão do mercantilista inglês James Stweart), a generalidade dos escritores mercantilistas não se cansa de sublinhar as vantagens da iniciativa privada, da liberdade de comércio e da concorrência entre produtores e comerciantes.

É importante salientar, aliás, que muita da actividade regulamentadora dos estados mercantilistas procurava justamente proporcionar às manufacturas privadas as condições mais favoráveis ao seu desenvolvimento, no período da "acumulação primitiva do capital". Bom exemplo disto mesmo é a regulamentação do trabalho nas manufacturas, num tempo em que a força e a violência desempenharam um papel decisivo nas relações entre os estados, mas também nas relações entre as classes sociais, mediadas quase sempre pela actuação do Estado. Este é um aspecto bem visível no domínio a que agora nos referimos.

$\mathrm{Na}$ Inglaterra, promulgou-se legislação que obrigava os pobres (e não apenas os internados nas Workhouses) a trabalhar nas manufacturas; institui-se um sistema público de fixação dos salários e toda uma legislação variada que procurou disciplinar a mão-deobra recém-chegada dos campos e fornecer à indústria manufactureira mão-de-obra abundante, obediente e barata.

$\mathrm{O}$ mercantilismo francês procurou pôr a funcionar um serviço nacional e obrigatório de emprego em benefício das manufacturas, às quais concedeu subsídios vários e procurou garantir posições monopolistas. Para estimular os empresários modernos, que pretendiam fugir à rotina e à estagnação das corporações de artes e ofícios, Colbert dá edifícios e instalações às manufacturas privadas; concede-lhes crédito a juro baixo, isenções e reduções de impostos; garante o aprovisionamento de matérias-primas a bom preço, através da isenção de direitos de importação e da autorização para a utilização gratuita das matas reais, quando necessário; assegura, por vários modos, o escoamento dos produtos manufacturados; desenvolve uma política populacionista, para que não falte a mão-de-obra (isenção temporária de impostos para os que se casem com menos de 20 anos; isenção de impostos para as famílias numerosas; proibição da emigração dos operários e apoio à imigração de operários estrangeiros qualificados; obrigação de as 
raparigas solteiras, os padres e as religiosas trabalharem na indústria, etc.).

De acordo com a filosofia social então corrente (com forte penetração dos valores religiosos saídos da Reforma), não se encontra na literatura mercantilista qualquer preocupação pela sorte da maioria constituída pelos pobres, 'mendigos' e 'vagabundos' gerados pelas vicissitudes económicas, sociais e políticas da época.

Como se diz acima, sob Henrique VIII e Isabel I várias leis prevêem a pena de morte para os mendigos reincidentes. Simultaneamente, outras leis visam organizar a assistência aos pobres: os fundos resultantes da cobrança de impostos locais especiais são utilizados para financiar a compra de cânhamo, linho e lã que permitam pôr os pobres a trabalhar. Em alguns casos, as administrações paroquiais alugam directamente esses pobres sem trabalho aos donos das manufacturas; noutros casos, os mendigos são internados nas Workhouses e obrigados a trabalhar nas manufacturas.

Também na França a mendicidade foi considerada crime contra o Estado. Em finais do séc. XVII é promulgada legislação que obriga a trabalhos forçados os vagabundos e os mendigos reincidentes; quanto às mulheres, prevê-se o ferrete, o degredo e o chicote. Nas manufacturas da seda de Lyon, o regulamento do trabalho (1667) obrigava a orações comunitárias de manhã e à tarde, trabalho das 4 às 20 horas ou das 6 às 22, com duas horas e meia de folga para as refeições, e a proibição de blasfemar, de fumar e de frequentar as tabernas. O regulamento das manufacturas de lanifícios de Amiens (1666) estipula que "nenhum mestre poderá tomar um operário que venha de outro mestre para trabalhar em sua casa sem saber se o primeiro mestre está contente com o operário”.

8 - Importa esclarecer, porém, que, na óptica dos mercantilistas, como mais tarde se viria a comprovar, não tem de haver contradição entre as exigências de intervenção regulamentadora do estado e de maior liberdade para as actividades económicas. Montchrestien é bem o exemplo de um mercantilista que atribui ao soberano a direcção geral da economia - defendendo que é a ele que cabe "ramener à l'ordre tout ce qui s'en est détraqué", "tenir l'oeil ouvert et l'oreille alerte, pour voir et entendre tout ce qui peut apporter du bien et du soulagement au peuple" -, mas sublinhando que a actuação do soberano deve ter em conta a iniciativa privada e o interesse pessoal, "ce grand aiguillon à bien faire", e pondo em relevo as vantagens da concorrência, "sans laquele l'action demeure toujours lâche et molle". O próprio Colbert sustenta que, "para desenvolver o comércio, há duas coisas necessárias, a segurança e a liberdade" - "laissez agir l'envie naturelle qu'ont les hommes de gagner quelque chose et de se mettre à leurs aises”, escreveu ele.

Nas condições históricas em que a reflexão dos mercantilistas se verificou e teve influência, a acção do estado, em aliança com os comerciantes, teve como primeiro objectivo aniquilar os poderosos corpos intermédios herdados da Idade Média. A intervenção do novo Estado (capitalista) visou, em última instância, garantir ao capital a liberdade e a segurança de que falava Colbert.

Uma das tarefas do poder central foi a de romper barreiras arcaicas, de pôr fim à intervenção das províncias, das comunas, 
das corporações, a de promover a unificação económica e política do espaço nacional. Conseguir este objectivo, à custa da redução ou anulação dos poderes económicos e políticos dos senhores feudais e das corporações artesanais urbanas era considerado condição indispensável para o desenvolvimento da liberdade económica da emergente classe burguesa. A liberdade, para os mercantilistas, não se definia negativamente (como o fariam os liberais dos sécs. XVIII e XIX), pela simples ausência de intervenção do estado. Para eles, nas palavras de Gonnard, a liberdade é antes "um poder de acção que se desenvolve com e pelo concurso do estado".

Encarada nesta perspectiva e à luz do seu tempo, a política mercantilista foi, sem dúvida, um factor de progresso: a acção do estado contribuiu para a generalização de técnicas industriais mais aperfeiçoadas e eficientes e foi a base da criação de verdadeiras economias nacionais. O que não significa que a manutenção rotineira dos regulamentos e até o excesso de intervencionismo não se tenham constituído, com o decurso do tempo, em obstáculos ao desenvolvimento económico.

Em síntese: historicamente, a doutrina mercantilista e a política mercantilista constituíram um contributo importante, no plano doutrinal e no plano da acção política, para a acumulação de capitais necessária à implantação do capitalismo como modo de produção dominante.

9- Como reacção contra o mercantilismo regulamentador surgiu a escola dos fisiocratas, desenvolvida à volta da obra e da personalidade de François Quesnay.
Identificando a propriedade com o "droit de jouir" e considerando este direito inseparável da "liberté de jouir", Mercier de La Rivière, um dos mais esclarecidos discípulos de Quesnay, defende que "atacar a propriedade é atacar a liberdade"; (...) perturbar a liberdade é perturbar a propriedade; assim, propriedade, segurança, liberdade, eis o que nós buscamos e o que devemos encontrar evidentemente nas leis positivas que nos propomos instituir; eis o que devemos considerar a razão essencial destas mesmas leis".

O domínio do proprietário sobre os seus bens é considerado "absoluto e sem limites (...); ele pode usar e abusar deles livremente, consumi-los, dá-los ou perdê-los. Este direito - refere Mercier de La Rivière - é inerente à sua plena propriedade". Este direito de propriedade, enquanto "direito natural e essencial" - afirma ainda este autor, com sublinhados nossos -, "é o primeiro princípio de todos os direitos e de todos os deveres recíprocos que os homens devem ter entre eles", pelo que "não pode haver direito onde não existe a propriedade", uma vez que é "impossível imaginar um direito que não seja um desenvolvimento, uma consequência, uma aplicação do direito de propriedade. Eliminem o direito de propriedade e não ficam quaisquer direitos", conclui de La Rivière.

A esta luz, a propriedade já não é a propriedade imperfeita da ordem feudal, mas a plena propriedade, a propriedade perfeita, a propriedade absoluta e sem limites da ordem burguesa emergente.

$\mathrm{Na}$ óptica dos fisiocratas, a estrutura social assenta na "grande distinção, a única fundada na natureza, entre duas classes, a dos proprietários das terras e a dos nãoproprietários", sublinhando Turgot que a 
distinção entre elas radica "nos seus interesses e por conseguinte nos seus direitos diferentes relativamente à legislação, à administração da justiça e da política, à contribuição para as despesas públicas e ao emprego".

Trata-se, sem dúvida, de uma distinção que tem por base a propriedade dos meios de produção (a terra e os avances feitos pelos proprietários) e a função que cada grupo social desempenha no processo económico de produção. E esta divisão da sociedade em proprietários de terras e não-proprietários tem incidências imediatas na esfera dos direitos económicos, sociais e políticos dos membros de cada uma das classes.

Com efeito, Mercier de La Rivière sustenta que os proprietários de terras são "os membros essenciais de uma nação" e sublinha que "o estado reside essencialmente no soberano, que é o chefe, nos proprietários do produto líquido e nos empreendedores de cultura". E Mirabeau é igualmente claro na afirmação de que só os proprietários gozam de direitos políticos e de que só eles são membros de pleno direito do estado: "O soberano e os proprietários do produto líquido e disponível eis o que compõe o estado".

Esta identificação da titularidade do poder social e político com o direito de propriedade explicam-na os fisiocratas invocando que a própria sociedade assenta na propriedade; que o estado existe para a protecção da propriedade e dos interesses dos proprietários; que são estes que pagam o impôt unique e que, por isso mesmo, "suportam o fardo das despesas públicas" (Turgot); que, acima de tudo, só os proprietários estão verdadeiramente 'enraizados' na sociedade e verdadeiramente interessados na prossecução dos objectivos da 'ordem natural'. Repare-se neste texto de Baudeau: "Um homem que incorpora os seus bens na terra, para a tornar mais frutificante, incorpora-se ele próprio nesse terreno, toma raiz no estado, se é permitido falar assim: a sua existência, as suas fruições estão intimamente ligadas ao território. Os proprietários fundiários pertencem portanto mais especialmente e mais intimamente a cada um dos Impérios". ${ }^{14}$ [sublinhado nosso. AN]

Dirigindo-se ao soberano, Turgot sublinha que "a lei sagrada da propriedade (...) é uma lei anterior às leis civis, cuja manutenção deve ser o único fim das instituições sociais". [sublinhado nosso] É ainda Turgot quem defende que "o interesse principal ao qual todos os outros estão subordinados é o interesse dos proprietários". Porque "é quando as suas propriedades forem tão protegidas quanto possível que eles extrairão a maior vantagem que puderem, que eles estarão interessados em valorizar quanto possível as suas terras, que as produções de todos os géneros se multiplicarão". A mesma tese é defendida pelo Marquês de Mirabeau: "o monarca acumula na sua pessoa dois direitos divinos, o da autoridade e o da propriedade; mas é o segundo que faz o primeiro. (...) O estado não tem, portanto, e não poderia ter interesses que não sejam também o interesse dos proprietários. Os direitos do estado são portanto os direitos dos proprietários".[sublinhado nosso]

A defesa da origem divina deste direito natural legitimador do direito de propriedade é um ponto essencial do pensamento fisiocrático. Le Trosne é muito claro a

\footnotetext{
${ }^{14}$ Cfr. A. VACHET, ob. cit., 387-390.
} 
este respeito: "O poder de fazer leis não pode pertencer aos homens, já que estes só poderiam abusar dele para sua perda e sua infelicidade. Deus reservou esse direito só para ele: a autoridade que ele confere aos homens não contém mais que um poder de execução, de aplicação e de administração". [sublinhado nosso] A mesma ideia é realçada por Dupont de Nemours: "as leis são todas feitas pela mão daquele que criou os direitos e os deveres. (...) As leis dos soberanos, que chamamos leis positivas, devem ser meros actos declaratórios daquelas leis essenciais da ordem social". Na síntese deste último autor: 'L'État est un législateur et non un légisfacteur, c'est un porteur de lois et non un faiseur de lois".

E Quesnay insiste em que "todos os homens e todas as potências humanas devem ser submetidas às leis soberanas instituídas pelo Ser Supremo", leis "imutáveis, irrefragáveis e as melhores leis possíveis". "A submissão exacta e geral a estas leis sagradas - leis que, nas palavras de Le Trosne, "prescrevem unicamente a conservação do direito de propriedade e da liberdade que é inseparável dele" - é condição essencial para a sobrevivência da própria sociedade". Estas leis, acentua Mercier de La Rivière, são "menos um presente da Divindade do que a própria Divindade": "pecar contra a lei é pecar contra a Divindade". [sublinhados nossos]

Os fisiocratas insistem (neste caso, o Marquês de Mirabeau) em que "é impossível que o governo tenha em algum local precedido a propriedade, uma vez que a propriedade é necessária para manter os homens juntos e formar a sociedade, e o governo não pode ter sido anterior à sociedade. $\mathrm{O}$ governo deriva portanto da propriedade e não a propriedade do governo".[sublinhados nossos]

E desta ideia de que o governo (i.é, o estado) só apareceu depois de (e por causa de) ter aparecido a propriedade deduzem os fisiocratas a tese de que o estado existe para defesa da propriedade, para "punir, pelo magistério dos magistrados, o pequeno número de pessoas que atentam contra a propriedade de outrem". É o que se exprime nesta afirmação do abade Baudeau: "Garantir a propriedade, defendê-la contra os usurpadores, assegurar a liberdade, isto é, o livre uso do direito de adquirir pelo seu trabalho ou de fruir depois de ter adquirido, é o objecto do poder protector, é o que ele deve operar pela justiça distributiva e pelo poder político ou militar".

A tarefa fundamental do Estado é, sem dúvida, para os fisiocratas, a de "assegurar entre os homens a propriedade e a liberdade, em conformidade com as leis naturais e essenciais da sociedade" (Mercier de La Rivière). O reconhecimento da natureza de classe do estado é inequívoco: o Estado (o direito, o poder judiciário, o poder político e o poder militar) está ao serviço dos proprietários.

Defendendo um conceito de propriedade próximo do conceito de propriedade burguesa (propriedade perfeita, absoluta e excluente), Dupont de Nemours define-a como "o direito exclusivo de possuir uma coisa qualquer". E Mercier de La Rivière reconhece que " propriedade exclui necessariamente a igualdade" e que " a diferença entre os ricos e os pobres torna-se cada dia mais marcada". Mas ele mesmo censura aqueles que se queixam da desigualdade, porque "não vêem que ela está na ordem da justiça". Pela 
palavra autorizada de Quesnay, os fisiocratas lembram que "a desigualdade do direito natural não admite justo nem injusto no seu princípio: ela resulta da combinação das leis da natureza". E Mercier de La Rivière: "O justo absoluto é uma justiça por essência, uma justiça que assenta de tal modo na natureza das coisas que seria necessário que elas deixassem de ser o que são para que esta justiça deixasse de ser o que ela é. O justo absoluto pode ser definido como uma ordem de direitos e de deveres que são de uma necessidade física e, por conseguinte, absoluta. Assim, o injusto absoluto é tudo o que se revela contrário a esta ordem (...). O que é de uma necessidade absoluta é também de uma justiça absoluta". Assim se compreende a célebre síntese de Quesnay: "Chez-nous, pour nous, tout est physique et le moral en derive". Assim se compreende a sentença do Marquês de Mirabeau: “As leis morais não são mais do que injunções à nossa liberdade no sentido de obedecer às leis físicas", que são leis naturais, leis que são a própria Divindade.

$\mathrm{O}$ recurso ao direito natural (= direito divino, produto da criação divina) em apoio da 'nova ordem burguesa' em gestação surge, a todas as luzes, como o modo mais expedito e mais eficiente de dar força a um estado e a um direito defensores dos valores burgueses, numa sociedade e num tempo em que a burguesia ainda não dominava completamente o aparelho de Estado, o Estado que faz as leis, o estado legislador, o Estado que cria o direito (o direito positivado nas leis aprovadas pelos parlamentos dominados pela burguesia revolucionária triunfante), como viria a ser o estado burguês.
10 - No que toca às relações entre o Estado e a economia, os fisiocratas confiam ao Estado o encargo de pôr de pé as infra-estruturas indispensáveis ao bom funcionamento da economia, como a construção e manutenção das grandes vias de circulação, a uniformização do sistema de pesos e medidas, a organização de um aparelho judiciário que assegure o reconhecimento dos contratos etc.

Mas não vão além disto. Os fisiocratas são adeptos do laissez-faire, laissez-passer, porque, a seu ver, a sociedade e a economia estão sujeitas - nas palavras de Mercier de La Rivière - àquelas "leis naturais e essenciais inerentes à ordem física, que nenhum poder é capaz de alterar". Dupont de Nemours lembra ao soberano que as suas funções "consistem principalmente em não impedir o bem, que se realiza por si próprio". E escreve em um outro trabalho: "O respeito pela liberdade e pela propriedade exige que os homens e os capitalistas permaneçam completamente senhores do uso dos seus capitais ("avances") e do seu tempo, desde que daí não resulte prejuízo para a liberdade nem dano para a propriedade de ninguém". Paz trop gouverner (...) laisser-les faire, eis a síntese da concepção de Dupont de Nemours. O mesmo conselho ao soberano é dado por Mirabeau: o que o governo tem de fazer é "se dispenser d'agir". Dito de outro modo (Mercier de La Rivière): o governo " $n$ ' a rien à faire; il lui suffit de ne rien empêcher".

Le Trosne sustenta igualmente que a função do soberano, a maior parte das vezes, é a de "laisser jouir les citoyens sans y intervenir", acreditando que "o que eles farão tendo em vista apenas o seu próprio interesse é o que eles podem fazer de mais vantajoso 
para a sociedade" e que o soberano "não pode fazer nada de mais injusto e ao mesmo tempo mais deplorável do que pretender restringir a sua [dos cidadãos] liberdade, regular o comércio, etc.”. Turgot defende igualmente que, perante os homens de negócios, o homem de Estado deve dizer-lhes apenas: "enrichessez-vous par le travail et par l'épargne", "faites ce que vous voudrez".

11 - Liberais no terreno da economia, os fisiocratas não foram liberais no que toca às liberdades políticas, domínio em que criticaram Montesquieu e outros defensores do ideário democrático e republicano. Para os fisiocratas, a autoridade do soberano funda-se na propriedade. Pela sua acção ao serviço da propriedade, a autoridade do soberano torna-se proprietária de toda a superfície do Estado, situação que se traduz no direito à cobrança do imposto. A prosperidade de cada um dos proprietários é, assim, a condição da prosperidade do monarca. Eis como Mercier de La Rivière expõe a tese fisiocrática da autoridade política (a "monarquia económica" ou o "despotismo legal", de que falava o abade Baudeau): "Qual é a melhor forma de governo? Qual é aquela que se apresenta tão conforme à ordem natural e essencial da sociedade que dela não possa resultar nenhum abuso? Esta melhor forma de governo é aquela que não permite que se possa ganhar governando mal e que, pelo contrário, obrigue aquele que governa a não ter outro interesse maior que o de bem governar".

"Que a autoridade soberana seja única e superior a todos os indivíduos da sociedade e a todos os empreendimentos injustos dos interesses particulares - escreve Quesnay -, porque o objectivo da autoridade e da obediência é a segurança e o interesse lícito de todos". E ainda Quesnay: "é preciso que a autoridade soberana, sempre esclarecida pela evidência, institua as melhores leis e as faça observar rigorosamente, para segurança de todos e para atingir a maior prosperidade possível da sociedade".

Turgot, embora admitisse uma assembleia representativa dos proprietários, confiava-lhe poderes meramente consultivos, reservando para o rei-déspota a actividade soberana, enquanto participante da propriedade universal. E defende assim as vantagens do despotismo esclarecido sobre a democracia: “(...) um déspota é limitado pelo seu próprio interesse; ele tem o freio do remorso ou da opinião pública; mas uma multidão não calcula nada; nunca tem remorsos, e atribui a glória a si própria, quando merece a maior vergonha".

Um bon despote, segundo os fisiocratas, deveria informar-se acerca das leis naturais e impor a sua observância, deixando-as actuar sem quaisquer entraves. Sujeito ele próprio às leis da natureza instituídas pelo Criador, não pode transgredi-las, sob pena de lesar os interesses dos súbditos e os interesses da sociedade.

12 - Sendo um dos pais fundadores do liberalismo, Adam Smith reconhece que os contratos livremente celebrados entre indivíduos livres e iguais em direitos são um modo normal (natural) de resolver as questões que se colocam na economia e na sociedade. O contratualismo é, com efeito, uma das pedras de toque do pensamento liberal.

É mérito deste pai fundador do liberalismo, no entanto, reconhecer, abertamente, que o 
contrato de trabalho não é um contrato como os outros, assim desmistificando um dos pilares fundamentais de toda a construção liberal. E não é, porque as duas partes que intervêm nesse 'contrato' não estão em posição de igualdade e porque uma delas (os trabalhadores) não são, verdadeiramente, livres de contratar ou não contratar (economicamente, são obrigados a trabalhar para sobreviver, porque, nada tendo de seu, além da "sua força e habilidade de mãos", "vivem dos salários").

Acompanhemos Adam Smith nas suas reflexões. Em primeiro lugar, observa que

"não é difícil prever qual das partes, em circunstâncias normais, levará sempre a melhor nesta disputa [a disputa entre os operários que "pretendem obter o máximo possível" e os patrões que "procuram pagarlhes o mínimo possível"] e obrigará a outra a aceitar os seus próprios termos. Os patrões, sendo em menor número, têm muito maior facilidade em associar-se; além disso, a lei autoriza, ou pelo menos não proíbe, as suas coligações, enquanto proíbe as dos trabalhadores. Não temos qualquer lei do parlamento contra as coligações destinadas a baixar o preço do trabalho, mas temos muitas contra aquelas que pretendam elevá-lo. Em todas as disputas desse género, os patrões podem resistir por muito mais tempo. Um proprietário, um rendeiro, um dono de fábrica, ou um comerciante, poderiam normalmente subsistir um ou dois anos sem empregar um único trabalhador, com base no pecúlio previamente acumulado. Muitos trabalhadores não conseguiriam subsistir uma semana, poucos subsistiriam um mês, e praticamente nenhum sobreviveria um ano sem emprego. A longo prazo, o operário pode ser tão necessário ao patrão como o patrão é necessário a ele, mas a necessidade não é tão imediata”.

Em segundo lugar, chama a atenção para o diferente tratamento que o estado (a lei) concede aos trabalhadores e aos patrões:
"Tem-se dito que é raro ouvir-se falar de coligações de patrões, enquanto se ouve com frequência falar nas dos operários. Mas quem quer que, com base nesse facto, imagine que os patrões raramente se coligam é tão ignorante do mundo como deste assunto. Os patrões mantêm sempre e por toda a parte uma espécie de acordo tácito, mas constante e uniforme, tendente a que os salários do trabalho se não elevem para além da taxa que vigora no momento. A violação de tal acordo é, em toda a parte, considerada como o mais impopular dos actos e constitui uma espécie de motivo de censura a qualquer patrão entre os seus próximos e iguais. É raro, na verdade, ouvirmos falar desse acordo porque ele corresponde à situação habitual, pode mesmo dizer-se natural, que jamais é comentada. Às vezes, os patrões entram também em coligações específicas para fazer descer os salários do trabalho ainda abaixo dessa taxa. Estas são sempre organizadas debaixo do maior silêncio e segredo, até serem postas em prática e, quando os trabalhadores cedem, como por vezes acontece, sem opor resistência, as outras pessoas nunca chegam a ouvir falar delas, por muito gravemente que pesem sobre os trabalhadores."

Em terceiro lugar, Adam Smith reconhece que, perante a desigualdade e a injustiça, é natural a reacção dos trabalhadores:

"Muitas vezes os trabalhadores organizam uma coligação defensiva para se lhes oporem; e também, às vezes, se organizam de motopróprio, sem que se tivesse verificado qualquer provocação desse género, para elevarem o preço do seu trabalho. As suas pretensões habituais incidem, umas vezes, sobre o alto preço das provisões, outras vezes, sobre o elevado lucro que os patrões auferem à custa do seu trabalho. Mas, quer estas coligações tenham carácter ofensivo, quer defensivo, ouve-se sempre falar delas em abundância. Para conseguirem uma decisão rápida, os trabalhadores recorrem sempre ao mais alto clamor e, em certos casos, à mais chocante violência e desacato. Sentem-se desesperados, 
e actuam com o delírio e imoderação de homens desesperados, a quem só resta morrer de fome ou, pelo medo, obrigar os patrões a aceitar imediatamente as suas reivindicações. Em tais circunstâncias, os patrões erguem, pelo seu lado, idêntico clamor, reivindicando incessantemente o auxílio das autoridades civis e o rigoroso cumprimento das leis destinadas a, com tanta severidade, se oporem às coligações de criados, trabalhadores e jornaleiros."

Perante homens desesperados, a quem só resta morrer de fome, é natural que os patrões tirem vantagem, até porque contam com o apoio do Estado ("o auxílio das autoridades civis"), que não só faz leis que proíbem com severidade as coligações de trabalhadores, mas impõe pela força o seu rigoroso cumprimento. Nestas condições, a relação de forças é claramente favorável aos empregadores capitalistas, que acabam sempre por obrigar a outra parte a "aceitar os seus próprios termos", conseguindo os patrões o seu objectivo de pagar aos operários "o mínimo possível."

Como se escrevesse nos nossos dias, Adam Smith deixa muito clara a sua ideia de que o estado não é neutro quando regula questões relativas às 'relações industriais': "sempre que a legislação procura regular os diferendos entre os mestres e os seus operários, é dos mestres que toma conselho." Resultado: "Sempre que a lei tem procurado regulamentar os salários dos trabalhadores, tem sido mais para os baixar do que para os subir.” Mais. Segundo Adam Smith, "quando a legislação favoreça os operários, ela é quase sempre justa e equitativa, o que nem sempre acontece quando é favorável aos mestres." Exemplo de uma lei "perfeitamente justa e equitativa", que favorece os operários, é, segundo Smith, "a lei que obriga os mestres de vários ofícios a pagar aos respectivos operários em dinheiro e não em géneros. Não impõe qualquer dificuldade real aos mestres. Apenas os obriga a pagar o valor em dinheiro daquilo que pretendiam pagar em bens, embora nem sempre o fizessem."

Muitas vezes - salienta Smith - os patrões associam-se "a fim de reduzir os salários dos operários, estabelecem normalmente entre si uma coligação ou acordo no sentido de não pagarem salários superiores a certo montante, sob determinadas penas"' E há leis - denuncia Adam Smith - que se limitam a "dar força de lei àquela mesma regulamentação que os mestres por vezes tentam impor por via de acordos privados." Como exemplo de lei injusta e não equitativa deste tipo, refere ele uma lei que "proíbe, sob pena de pesados castigos, a todos os mestres-alfaiates de Londres, ou de cinco milhas em redor, o pagarem, e a todos os oficiais o receberem, mais de dois xelins e sete dinheiros e meio por dia."

O Estado não está, pois, ao serviço dos interesses dos trabalhadores e a voz destes "é pouco ouvida e menos considerada nas deliberações públicas, excepto em casos particulares, quando o seu clamor é animado, incitado e apoiado pelos patrões, não com o fim de servir os interesses dos trabalhadores, mas os seus". Nestas condições, conclui Adam Smith, "os trabalhadores raramente tiram qualquer vantagem da violência dessas coligações tumultuosas que, em parte por força da intervenção das autoridades civis, em parte devido à maior resistência dos patrões, e ainda em parte devido à necessidade em que a maior parte dos trabalhadores se vê de se submeter para garantir a sua subsistência imediata, geralmente ficam em nada, salvo 
pelo que respeita à punição ou ruína dos chefes do movimento."

13 - Interrogando-se sobre a questão de saber se a melhoria das condições de vida das classes mais baixas do povo deve ser considerada uma vantagem ou um inconveniente para a sociedade, Adam Smith responde deste modo:

"A resposta parece, à primeira vista,
absolutamente óbvia. Os criados, os
trabalhadores agrícolas e os operários de
diferentes tipos constituem de longe a maioria
em qualquer grande sociedade política. E o
que melhora as condições de vida da maior
parte nunca pode ser considerado prejudicial
ao todo. Nenhuma sociedade pode certamente
ser florescente e feliz, se a maior parte dos
seus membros for pobre e desgraçada. Além
disso, não é mais do que simples equidade
que aqueles que alimentam, vestem e
proporcionam habitação a todo o conjunto de
pessoas, desfrutem de uma parcela do produto
do seu próprio trabalho que lhes baste para
que andem eles próprios sofrivelmente bem
alimentados, vestidos e abrigados".

Quer dizer: quem cria a riqueza deve receber, pelo menos, uma parte dela para prover sofrivelmente às suas necessidades básicas (em termos compatíveis "com um mínimo de humanidade", nas palavras de Smith).

O professor de Glasgow não ignora, no entanto, o carácter conflituante da sociedade em que se insere e revela mesmo a percepção de que o conflito essencial presente nesta sociedade é o que opõe os trabalhadores assalariados e os proprietários do capital, classes "cujos interesses não são de modo algum idênticos".

Esta diferença de posições (e consequente antagonismo de interesses) explica-a Smith como consequência dos diferentes poderes de que dispõem, nas sociedades capitalistas (nas sociedades em que "o trabalhador é uma pessoa e o proprietário do capital, que o emprega, é outra"), os patrões (por serem "proprietários do capital") e os operários (por possuírem apenas "a sua força e habilidade de mãos", por não possuírem "o capital suficiente, tanto para comprar as matériasprimas necessárias ao seu trabalho, como para se manter até ele se achar terminado"). Tudo se reduz ao facto de uma classe de pessoas deter a propriedade do capital e outra classe estar privada dela.

As relações sociais não aparecem, pois, na obra de Smith, como relações entre indivíduos iguais. Ele tem clara consciência de que "sempre que há muita propriedade, há grande desigualdade", de que "por cada homem rico haverá, pelo menos, quinhentos homens pobres", e de que "a propriedade de uns poucos pressupõe a indigência de muitos". E sabe que nas "nações civilizadas e prósperas (...) um grande número de pessoas não exerce qualquer actividade e muitas delas consomem o produto de dez vezes, frequentemente de cem vezes, mais trabalho do que aqueles que as exercem".

A verdade, porém, é que Smith entende que a economia funciona segundo leis naturais, tão naturais como as leis da física. Por isso, fiel à sua filosofia individualista (porventura algo contraditória com a importância que atribui à divisão do trabalho), sustenta que a vida económica decorrerá harmoniosamente desde que se deixem as coisas seguir o seu curso natural.

Coerentemente, Adam Smith não admite nenhum tipo de intervenção do Estado com fins correctivos. Porque "ferir os interesses de 
uma classe de cidadãos, por mais ligeiramente que possa ser, sem outro objectivo que não seja o de favorecer os de qualquer outra classe, é uma coisa evidentemente contrária àquela justiça, àquela igualdade de protecção que o soberano deve, indistintamente, aos seus súbditos de todas as classes."

Como bom liberal, Adam Smith defende que o máximo de utilidade social se consegue quando a vida económica decorre naturalmente, prosseguindo cada um o seu próprio interesse. Segundo esta concepção, a economia (separada do estado) funciona de acordo com as suas próprias leis, leis naturais, leis de validade absoluta e universal: a ordem natural harmoniza todos os interesses a partir da natural actuação de cada um no sentido de obter o máximo de satisfação com o mínimo de esforço. Deste "fetichismo naturalístico" (Oskar Lange) derivam os economistas clássicos duas considerações fundamentais:

a) por um lado, uma atitude conformista perante as ocorrências da vida económica: elas decorrem das leis da natureza e o que é natural é justo (a lei moral identifica-se com a lei natural);

b) por outro lado, uma atitude de condenação de toda e qualquer intervenção do Estado na vida económica. Em $1^{\circ}$ lugar, porque a vida económica e a ordem social são consideradas partes integrantes da ordem natural, regulada por leis que exprimem princípios eternos e universais da natureza humana, leis tão rigorosas e inalteráveis como as leis da física (concepção mecanicista ou fisicista, de raiz newtoniana); em $2^{\circ}$ lugar, porque defendem que o Estado, como máquina essencialmente política, é, pelas suas próprias funções, incompetente para a actuação económica (Smith: "não há dois caracteres que pareçam mais contrários do que os do comerciante e do governo.").

14 - A vida económica, assim entendida, é o fundamento da sociedade civil, o princípio da própria existência do Estado, cujas funções devem restringir-se ao mínimo compatível com a sua capacidade para garantir a cada um e a todos, em condições de plena liberdade, o direito de lutar pelos seus interesses como melhor entender.

Adam Smith é considerado o 'pai' da doutrina do Estado mínimo e é muitas vezes invocado, nesta qualidade 'paternal', para justificar as propostas dos neo-liberais dos nossos dias.

É claro o ponto de vista de Smith a este respeito:

"O soberano fica totalmente liberto (...) do dever de superintender o trabalho das pessoas privadas e de o dirigir para as actividades mais necessárias à sociedade. Segundo o sistema de liberdade natural, o soberano tem apenas três deveres a cumprir. Três deveres de grande importância, na verdade, mas simples e perceptíveis para o senso comum: em primeiro lugar, o dever de proteger a sociedade da violência e das invasões de outras sociedades independentes; em segundo lugar, o dever de proteger, tanto quanto possível, todos os membros da sociedade da injustiça ou opressão de qualquer outro membro, ou o dever de estabelecer uma administração da justiça; e, em terceiro lugar, o dever de criar e preservar certos serviços públicos e certas instituições públicas que nunca poderão ser criadas ou preservadas no interesse de um indivíduo ou de um pequeno número de indivíduos, já que o lucro jamais reembolsaria a despesa de qualquer indivíduo ou pequeno número de indivíduos, embora possa, muitas vezes, fazer mais do que reembolsar esse lucro a uma grande sociedade". 
Mas cremos que esta tese de Smith tem em vista as estruturas do poder político do estado absoluto, ao serviço de interesses de tipo feudal, que o filósofo criticou por ineficientes e improdutivas: "na maior parte dos países, a totalidade ou a quase totalidade das receitas públicas é empregada na manutenção de indivíduos não produtivos". Entre estes indivíduos não produtivos inclui Adam Smith "muitas das mais respeitáveis classes sociais, (...) o soberano, por exemplo, bem como todos os funcionários tanto da justiça como da guerra que servem sob as suas ordens, todo o exército e toda a marinha", "todos os que compõem uma corte numerosa e esplêndida, uma grande instituição eclesiástica, armadas e exércitos poderosos que em tempos de paz nada produzem e em tempos de guerra nada adquirem que possa compensar o dispêndio incorrido com a sua manutenção, ainda que só durante o período de duração da guerra. Toda essa gente - remata Adam Smith -, dado que nada produz, tem de ser mantida pelo produto do trabalho de outros homens".

É este 'Estado' parasita e perdulário que Adam Smith pretende reduzir a Estado mínimo. Com esta justificação:

"quando se multiplicam [essa gente e essas estruturas] para além do necessário, podem, num ano, consumir uma parcela tão elevada daquele produto [o produto do trabalho de outros homens] que a parte restante não baste para manter os trabalhadores produtivos, necessários à reprodução do ano seguinte. Assim, a produção do ano seguinte será inferior à desse ano e, se se mantiver o mesmo desconcerto, a do ano a seguir reduzirse-á ainda mais. Pode acontecer que esses indivíduos improdutivos, que deviam ser mantidos apenas por uma parte do rendimento disponível do conjunto das pessoas, cheguem a consumir uma parcela tão grande da totalidade do rendimento, obrigando tão elevado número de indivíduos a consumir o respectivo capital, ou seja, os fundos destinados à manutenção do trabalho produtivo, que a frugalidade e o adequado emprego dos capitais por parte dos indivíduos não seja suficiente para compensar a perda e degradação do produto originadas por esse violento e forçado abuso".

Esta apreciação de Adam Smith poderá aplicar-se ainda hoje a muitos estados dominados por oligarquias corruptas e por ditadores sem escrúpulos, mas não serão inteiramente adequadas à situação dos estados democráticos em países de economias complexas e desenvolvidas.

Por outro lado, é de salientar a preocupação de Smith em responsabilizar o Estado por uma série de serviços públicos, deixando claro que é dever do soberano "a criação e a manutenção daqueles serviços e instituições que, embora possam ser altamente benéficos para uma sociedade, são, todavia, de uma natureza tal que o lucro jamais poderia compensar a despesa para qualquer indivíduo ou pequeno número de indivíduos, não se podendo, portanto, esperar a sua criação e manutenção por parte de qualquer indivíduo ou pequeno número de indivíduos. A concretização deste dever exige despesas de variadíssimos graus nos diferentes períodos da sociedade."

Depois das instituições públicas e dos serviços públicos necessários para a defesa da sociedade e para a administração da justiça-acrescenta Smith - os outros serviços e instituições deste tipo são fundamentalmente aqueles criados com vista a facilitar o comércio da sociedade e a promover a instrução do povo." E, num toque de grande modernidade, conclui: "As instituições de instrução são de dois tipos: as que visam a instrução da juventude e as que visam a de pessoas de todas as idades". 
A verdade é que, entre os neoliberais de hoje, não falta quem considere demasiado permissivo e 'perigoso' o critério de Smith para delimitar a acção do Estado:

"Quase não há nenhuma actividade - escreveu Milton Friedman em 1976 - que não se tenha considerado adequada à intervenção do estado de acordo com os argumentos de Smith. É fácil afirmar, como o faz Smith mais de uma vez, que há 'efeitos externos' que colocam uma actividade ou outra na esfera do 'interesse público', e não na esfera do 'interesse de algum indivíduo ou algum número pequeno de indivíduos'. Não há critérios objectivos amplamente aceites para avaliar tais asserções, para medir a grandeza dos efeitos externos, para identificar os efeitos externos das acções governamentais e compara-los com os efeitos externos que se produziriam se se deixassem as coisas em mãos privadas. A análise superficialmente científica de custo-benefício erigida com base em Smith transformou-se numa formidável Caixa de Pandora”.

15 - Escrevendo quando o Estado capitalista dava os primeiros passos, a análise de Adam Smith sobre a origem e a evolução do estado assenta numa interpretação histórica. Certos trechos de Riqueza das Nações lembram alguns trabalhos de Engels sobre este mesmo tema.

Como "a avareza e a ambição nos ricos e o ódio ao trabalho e a tendência para a preguiça nos pobres - escreve ele, não escapando aqui às ideias feitas do pensamento dominante no século XVIII - constituem as paixões que predispõem ao ataque à propriedade", e como "a propriedade dos ricos provoca a indignação dos pobres que muitas vezes são levados pela necessidade e influenciados pela inveja a apropriar-se dos seus bens", compreende-se a necessidade do "estabelecimento de um governo civil" e compreende-se que uma das funções do Estado seja a da administração exacta da justiça, uma vez que "é só com a protecção do magistrado civil que o dono dessa valiosa propriedade, adquirida com o trabalho de muitos anos ou, talvez, de muitas gerações, poderá dormir em segurança." "A aquisição de propriedades valiosas e vastas - conclui Adam Smith - exige, necessariamente, o estabelecimento de um governo civil. Quando não há propriedades ou, pelo menos, propriedades que excedam os dois ou três dias de trabalho, o governo civil não será tão necessário".

Particularmente elucidativos do que se diz atrás são os trechos seguintes:

"Como, entre caçadores, raramente existe a propriedade ou, pelo menos, propriedades superiores a dois ou três dias de trabalho, raramente existe qualquer magistrado, ou qualquer administração regular da justiça."

"É na era dos pastores, no segundo período da sociedade - escreve mais à frente Adam Smith -, que surge pela primeira vez a desigualdade de fortuna, introduzindo no seio dos homens um grau de autoridade e subordinação anteriormente impossível de existir. Introduz, assim, em certa medida, esse governo civil indispensável à sua própria manutenção e parece tê-lo feito naturalmente, independentemente, mesmo, da verificação dessa necessidade. Esta verificação vai acabar, sem dúvida, por contribuir muito para a manutenção e consolidação dessa autoridade e subordinação. Os ricos especialmente estão necessariamente interessados em manter esse estado de coisas, único capaz de lhes assegurar os seus próprios benefícios. Os menos ricos unem-se na defesa dos mais ricos no que se refere à sua propriedade para que, por sua vez, estes se unam na defesa da propriedade daqueles. Todos os pastores e criadores menores sentem que a segurança dos seus próprios rebanhos dependem da segurança dos rebanhos dos pastores e criadores mais prósperos, que a manutenção da sua menor autoridade depende da manutenção da 
autoridade superior e que da sua subordinação depende o poder de, por seu turno, subordinar outros que lhe são inferiores. Constituem uma espécie de aristocracia que tem todo o interesse em defender a propriedade e em apoiar a autoridade do seu pequeno soberano a fim de este poder defender a sua própria propriedade e apoiar a sua autoridade".

Logo a seguir, Adam Smith torna bem clara a sua concepção do Estado enquanto instrumento de defesa dos proprietários contra aqueles que não dispõem da propriedade do capital. Na esteira de Locke (Civil Government, § 94: “o governo não tem qualquer outro objectivo que não seja a preservação da propriedade"), Smith defende que "o governo civil, na medida em que é instituído com vista à segurança da propriedade, é, na realidade, instituído com vista à defesa dos ricos em prejuízo dos pobres, ou daqueles que possuem alguma propriedade em detrimento daqueles que nada possuem".

São afirmações como esta que justificam a tese de Mark Blaug segundo a qual, nesta Parte II do Capítulo I do Livro V de Riqueza das Nações, Smith "apresenta uma teoria 'marxista' do estado". ${ }^{15}$ E talvez esta leitura permita compreender melhor a coerência da rejeição, por parte de Smith, de qualquer

${ }^{15}$ Cfr. M. BLAUG, Economic Theory...., 61. É também de Mark Blaug este comentário: "Quando lemos as suas análises sobre a evolução do governo civil, da justiça, das forças armadas e da família, torna-se evidente que ele tinha ideias claras sobre a natureza do processo histórico. Como outros autores escoceses da época, v.g. Adam Ferguson, John Millar, Willam Robertson e mesmo David Hume, ele expõe uma filosofia da história que atribui uma importância fundamental à natureza e à distribuição da propriedade. Não é exagerado descrever estes homens como os precursores da 'concepção materialista da história"”. intervenção do estado com vista à correcção das injustiças: exactamente porque sabe qual é o verdadeiro papel do estado e aceita que ele deve cumprir a sua função, que é "a defesa dos ricos em prejuízo dos pobres, ou daqueles que têm alguma propriedade em detrimento daqueles que nada possuem".

16 - Coerente com os valores da teologia da Reforma que tão claramente se reflectem na explicação que deu da previous accumulation, Smith defende (tal como os demais autores da Escola Clássica inglesa) que a propriedade (a acumulação do capital) é o fruto da frugalidade e da prudência de alguns, é "adquirida com o trabalho de muitos anos ou, talvez, de muitas gerações".

E pensa que todos podem ser proprietários, mesmo o mais pobre dos homens, "se for frugal e industrioso.” Dir-se-ia que "o ódio ao trabalho e a tendência para a preguiça e para o ócio nos pobres" é que explicam as diferenças sociais, que não seriam, aliás, tão gritantes como poderiam sugerir certas passagens de Riqueza das Nações.

O melhor é lermos o que escreve o próprio Adam Smith:

"Nas nações civilizadas e prósperas, embora um grande número de pessoas não exerça qualquer actividade e muitas delas consumam o produto de dez vezes, frequentemente de cem vezes, mais trabalho do que aquelas que as exercem, ainda assim o produto de todo o trabalho da sociedade é tão grande que, em geral, se encontram abundantemente providas, e um trabalhador, ainda que da classe mais baixa e mais pobre, se for frugal e industrioso, poderá usufruir de uma quota-parte maior de bens necessários à vida e ao conforto do que qualquer selvagem".

É ainda Smith quem escreve: 
"O estômago do rico está em proporção com os seus desejos e não comporta mais que o do aldeão grosseiro. (...)

Uma mão invisível parece forçá-los [aos ricos] a concorrer para a mesma distribuição das coisas necessárias à vida que se teria verificado se a terra tivesse sido dada em igual porção a cada um dos seus habitantes; e assim, sem ter essa intenção, sem mesmo o saber, o rico serve o interesse social e a multiplicação da espécie humana. A Providência, distribuindo, por assim dizer, a terra entre um pequeno número de homens ricos, não abandonou aqueles a quem parece ter-se esquecido de atribuir um lote, e eles têm a sua parte em tudo o que ela produz. (...) Quanto ao que constitui a verdadeira felicidade, não são inferiores em nada àqueles que parecem colocados acima deles. Todos os escalões da sociedade estão ao mesmo nível pelo que respeita ao bem-estar do corpo e à serenidade da alma, e o mendigo que se aquece ao sol ao longo de uma sebe possui ordinariamente aquela tranquilidade que os reis sempre perseguem".[sublinhado nosso]

Dominado pela visão fisiocrática de uma sociedade que funciona perfeitamente por si, como um 'organismo natural' - na qual não deve tocar-se para a não descontrolar -, Adam Smith alicerça a sua filosofia social em dois valores fundamentais: a confiança no sistema de liberdade natural e a aceitação da justiça realizada pela mão invisível. E não se 'comove' com as desigualdades: aos pobres pertence a serena e tranquila felicidade de poderem aquecer-se ao sol ao longo de uma sebe, felicidade que os reis sempre perseguem... Não há que duvidar: Estado (o Estado capitalista) existe para acautelar outros interesses que não os dos pobres.

\section{ANTÓNIO JOSÉ AVELÃS NUNES}

Professor Catedrático da

Faculdade de Direito de Coimbra

\section{REFERÊNCIAS}

BLAUG, Mark. Economic Theory in Retrospect, 5.ed., Cambridge University Press, 1985.

CONTE, Giuliano. Da crise do Feudalismo ao Nascimento do Capitalismo (1 ${ }^{a}$ ed. it., 1976), trad. port., Editorial Presença/Martins Fontes, Lisboa, 1979.

GALBRAITH, J. K. Anatomia do Poder (1. a ed. americana, 1983), trad. port., Difel, Lisboa, s/d.

GUERREAU, Alain. O Feudalismo - Um horizonte teórico, trad. port., Edições 70, Lisboa, s/d (1. ${ }^{a}$ ed. francesa, 1980).

MANDEL, Ernest. Traité d'Économie Marxiste (4 vols.), Union Générale d'Éditeurs, Paris, 1962.

MARX, Karl. Le Capital (trad. de J. Roy), Paris, Garnier- Flammarion, 1969.

MARX, Karl. O Capital, Edições Avante (edição dirigida por José BARATA MOURA e Francisco MELO), 3 Vols. (Livro Primeiro, Tomo I, Tomo II e Tomo III), Lisboa, 1990, 1992 e 1997.

MARX/ENGELS. Obras Escolhidas, trad. port. 3 tomos, Lisboa, Edições Avante, 1982, 1983 e 1985.

PARAIN, Charles; Pierre VILAR e outros. $E l$ Feudalismo, trad. cast., Editorial Ayuso, Madrid, 1972.

QUESNAY, François. Quadro Económico, trad. port., Lisboa, Fundação Calouste Gulbenkian, 1969 (todas as citações de François Quesnay reportam-se a esta edição).

SMITH, Adam. Ensaio sobre a Natureza e as Causas da Riqueza das Nações, trad. port., Lisboa, Fundação Calouste Gulbenkian, 2 vols., 1981 e 1983 (todas as citações de A. Smith reportam-se a esta edição).

VACHET, André. L'idéologie libérale L'individu et sa propriété, Paris: Anthropos, 1972 (todas as citações de autores fisiocratas, salvo François Quesnay, foram colhidas nesta obra). 